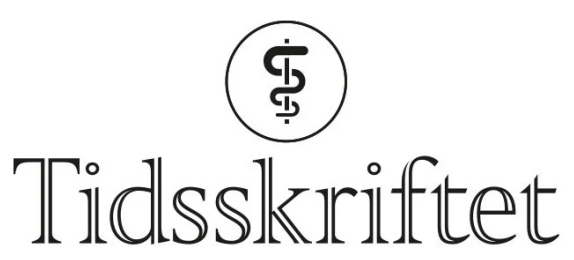

DEN NORSKE LEGEFORENING

\title{
Den absolutte selvbestemmelsesrett i medisinsk forskning - tjener den befolkningen?
}

HELSE OG JUS

\section{PEDER HEYERDAHL UTNE}

Peder Heyerdahl Utne (f. 1969)

er spesialrådgiver cand.jur. og Master of Management, seksjon for forskningsadministrasjon, Oslo universitetssykehus. Spesialområde er helseforskningsrett, etikk og personvern. Ingen oppgitte interessekonflikter.

Email: pederhu@medisin.uio.no

Seksjon for forskningsadministrasjon

Oslo universitetssykehus

\section{Personvern i medisinsk forskning må ikke marginaliseres til et spørsmål om samtykke. I så fall er det en fare for at vi undergraver befolkningens forventninger til helsetjenesten.}

Selvbestemmelsesretten og forskningsdeltakernes råderett over eget legeme, biologisk materiale og helseopplysninger er nedfelt i en rekke lovfestede og ulovfestede normer. I helseforskningsloven fremgår det klart og tydelig at det kreves samtykke fra deltakerne i medisinsk og helsefaglig forskning (1). I likhet med den generelle personvernlovgivningen, er kravet til samtykke etter helseforskningsloven formulert som en hovedregel, der unntak bare kan skje der dette er hjemlet i annen lov ( $\left.\S_{13}\right)$. I forskningsetikken er selvbestemmelsesprinsippet forankret i kravet om at forskning på mennesker skal være basert på respekt for deltakernes menneskerettigheter og menneskeverd, og at hensynet til deltakernes velferd og integritet skal gå foran

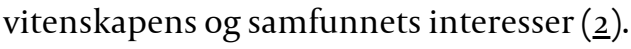

Skal imidlertid regulering av selvbestemmelsesretten i medisinsk og helsefaglig forskning reflektere en dypere hensikt, kan ikke spørsmålet om rekkevidden av samtykkekravet frikobles fra forskningens plass i samfunnet og forholdet mellom fellesskapet og enkeltindividet. Det er heller ikke mulig å besvare dette spørsmålet uten å se selvbestemmelse og samtykke i sammenheng med andre kontroll- og personverntiltak.

Forskning og borgerne 
Den medisinske og helsefaglige forskning er på mange måter et løpende samfunnsmessig prosjekt, der forskerne og individene i fellesskap - på hver sin måte - bidrar i utviklingen av en bedre helsetjeneste. Vi som enkeltindivider ikke bare forventer, men forlanger å få den beste behandling når sykdom oppstår. Innenfor gitte rammer har derfor den enkelte av oss en etisk forpliktelse til å bidra i den medisinske og helsefaglige utvilkling til det beste for fellesskapet. Helseundersøkelsen i Nord-Trønderlag (HUNT) er et eksempel på dette. Deltakerne i HUNT bidrar, gjennom å avgi spørreskjemadata og biologisk materiale, i en felles dugnad for en «bærekraftig befolkningsbasert forskningsstrategi» (3).

Å basere all medisinsk forskning utelukkende på en fellesskapstilnærming, har imidlertid en særdeles dårlig historisk gjenklang (4.). For den enkelte gir kravet til samtykke trygghet om, og avspeiler respekt for, våre rettigheter som selvstendige individer. På den annen side bør det etiske og juridiske utgangspunkt for selvbestemmelsesretten vurderes i lys av hvor inngripende forskningen er overfor deltakerne. Det går et hovedskille mellom eksperimentell forskning som involverer mennesker direkte, og forskning som utelukkende innebærer bruk av biologisk materiale eller helseopplysninger samlet inn i helsetjenesten.

\section{Forskning som involverer mennesker direkte}

Det er i helseforskningsloven lagt klare rammer for når det etisk og juridisk er forsvarlig å forske direkte på mennesker. Grunnen til dette er åpenbar, og følger av det ansvar storsamfunnet har for å beskytte borgerne mot direkte skade og ubehag. I så måte er også krav til samtykke av vesentlig betydning. Forskningsdeltakerne skal ha mulighet til selv å vurdere eventuell nytte og risiko ved egen deltakelse. Samtykke er imidlertid ikke i seg selv tilstrekkelig for å si at forskningen er etisk og juridisk forsvarlig. Sigmund Simonsen redegjør i sitt doktorgradsarbeid fra 2010 for proporsjonalitetskravet i medisinske forskning (5). I korthet går proporsjonalitetskravet ut på at forskere har en selvstendig plikt til å identifisere, vurdere og avveie eventuelle risikoer, belastninger og fordeler for deltakerne. Dersom risikoer og belastninger ved deltakelse overstiger fordelene, kan dette medføre at det verken er etisk eller juridisk forsvarlig å gjennomføre prosjektet, uavhengig av om det foreligger samtykke. En tilsvarende tilnærming ses i straffeloven, der direkte intervensjoner i form av fysiske inngrep basert på samtykke ikke nødvendigvis er straffebefriende.

Med forskning på mennesker menes også forskning som er mindre inngripende, så som helseundersøkelser i form av spørreskjemadata eller rene observasjonsstudier. Selv om det her ikke er naturlig å snakke om risiko for fysiske skader, så kan prosjektet medføre psykisk belastning og ubehag for deltakerne. Krav til samtykke i slike studier er derfor også et naturlig utgangspunkt, samtidig som samtykke i seg selv vil bidra til å skape tillit mellom forsker og deltakere.

Det er på denne bakgrunn gode etiske og juridiske grunner for samtykkekravet når forskningen involverer mennesker direkte. Derfor bør det utøves tilbakeholdenhet ved vurdering av om det er akseptabelt å fravike denne hovedregelen med henvisning til fellesskapets interesser.

\section{Forskning på humant biologisk materiale og helseopplysninger}

Forskning på humant biologisk materiale og helseopplysninger samlet inn i helsetjenesten følger i utgangspunktet samme hovedregel som den pasientnære forskningen. Dette betyr at all forskning på humant biologisk materiale og helseopplysninger, uansett om det er samlet inn fra før, skal bygge på informert, frivillig, uttrykkelig og dokumentert samtykke fra avgiver. Det er særlig på dette punkt at en for rigid fortolkning av 
selvbestemmelsesretten har sine slagsider. Dette ved blant annet ikke å ta hensyn til den rolle forskningen har i utvikling og kvalitetssikring av helsetjenesten, og deltakernes åpenbare interesse av at slik forskning gjennomføres på en kostnadseffektiv måte.

For prosjekter som utelukkende omfatter bruk av tidligere innsamlet materiale og data, er risikoaspektet i form av direkte skade og ubehag betydelig redusert, om ikke fraværende. Rekkevidden av individets autonomi med tanke på denne type forskning bør derfor i større grad kunne baseres på en etisk avveining mellom henholdsvis samfunnets interesse av at forskningen gjennomføres, og hensynet til deltakernes velferd og integritet. Selv om helseforskningsloven åpner for nettopp en slik interesseavveining, er min erfaring at samtykke av enkelte formuleres som en «absolutt regel» uten at også andre personverntiltak blir gjort til gjenstand for en like grundig vurdering.

Det er i denne sammenheng viktig å huske at det skriftlige samtykket i seg selv på langt nær er det optimale forsvarsverk mot krenkelser av forskningsdeltakernes integritet og privatliv. Tvert imot viser studier at deltakernes evne til å forstå konsekvensene av egne beslutninger ofte er omvendt proporsjonal med omfanget av den informasjon som ligger til grunn for samtykke (므). Den avtalerettslige forståelse av det skriftlige samtykke er derfor et lite egnet utgangspunkt. Dette fordi de færreste av oss noen gang vil ha tilstrekkelige forutsetninger for å vurdere alle konsekvenser av egen deltakelse.

Dette reiser spørsmål om ikke det Ola Berger beskriver som «Fra informert til fordekt samtykke» (ㅁ), bør få en tydeligere plass i den forskningsetiske vurdering. Dette fordrer samtidig at lovgiver og relevante myndigheter er villig til å se beskyttelse og respekt for forskningsdeltakerne i et bredere personvernperspektiv.

\section{Personvern og samtykke}

Personvern er ikke noe entydig begrep. I personopplysningslovens formålsbestemmelse fremgår det at loven skal beskytte den enkelte mot at personvernet krenkes gjennom behandling av helseopplysninger (7.). Videre heter det at loven skal bidra til at personopplysninger blir behandlet i samsvar med grunnleggende personvernhensyn, herunder behovet for personlig integritet, privatlivets fred og tilstrekkelig kvalitet på personopplysningene. Krav til samtykke er med dette ikke ensbetydende med personvern, men ett av flere viktige elementer i den personvernmessige vurdering. Dette er et viktig poeng og følger implisitt av personopplysningsloven, der behandlingen av sensitive personopplysninger som inngår i et allmennyttig forskningsprosjekt ( $\S \S 8 \mathrm{e}, 9 \mathrm{~h}$ ) under gitte forutsetninger er likestilt med samtykke.

Denne problemstillingen er utførlig drøftet i en artikkel av Ruyter og medarbeidere om samtykkeproblematikken i forskningsprosjekter som omfatter store mengder data fra biologisk materiale og helseregistre (므). Forfatterne peker blant annet på at EUs personverndirektiv (9.), som også vår personopplysningslov bygger på, ikke er kategorisk når det gjelder samtykkekravet i forskning av allmennyttig interesse. Samtidig - og kanskje vel så viktig - viser forfatterne til at det for denne type forskning finnes en rekke andre mekanismer med formål å sikre deltakernes interesser. Krav om forhåndsgodkjenning av forskningsprosjektet i uavhengige etiske komiteer, krav til internkontroll og informasjonssikkerhet, tilsyn med forskningsprosjekt, plikten til å informere deltakerne om prosjektet og retten til å reservere seg mot deltakelse er alle sentrale personverntiltak, samtidig som det legges til rette for samfunnsnyttig forskning.

Hva bør så de grunnleggende personvernhensyn bygge på?

\section{Forhåndsgodkjenning, forsvarlighet og tillit}


Det følger av helseforskningsloven at medisinsk og helsefaglig forskning skal organiseres og utøves forsvarlig. Forsvarlighetsvurderingen etter helseforskningsloven harmoniserer

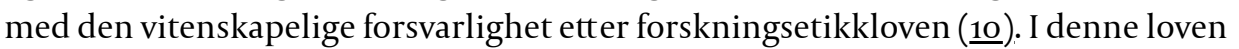
fremgår det at medisinske og helsefaglige forskningsprosjekter skal bygge på anerkjente etiske lovfestede og ulovfestede normer med det formål å beskytte forskningsdeltakerne. De regionale komiteene for medisinsk og helsefaglig forskningsetikk (REK) har en helt avgjørende rolle i forståelsen av hva som til enhver tid skal betraktes som etisk forsvarlig forskning. Samtidig hviler det en betydelig forpliktelse på de ansvarlige for prosjektet (institusjon og prosjektleder) for å påse at prosjektet planlegges, gjennomføres og avsluttes på en etisk og juridisk forsvarlig måte. Den forskningsetiske og den juridiske forsvarlighetsvurdering står i så måte på egne bein, idet et samtykke på ingen måte fritar forskerne fra å opptre forsvarlig.

Forskningsdeltakernes grunnleggende interesser vil på denne bakgrunn først og fremst være forankret i kravet om forsvarlighet. Et tverrfaglig og kompetent komitésystem (REK) vil med sin forhåndsgodkjenning fungere som premissleverandør, i overensstemmelse med den forskningsetiske interesseavveining som helseforskningsloven forutsetter. Som borgere må vi, uavhengig av samtykke, ha tiltro til at komiteene og de ansvarlige for prosjektet sikrer at våre interesser ivaretas både som individer og som en del av et fellesskap som fremmer samfunnsnyttig forskning. Det er i utgangspunktet dette tillitsforholdet som legitimerer den medisinske og helsefaglige forskningen.

Forsvarlighetsvurderingen og personvernet må på sin side ikke marginaliseres til et spørsmål om samtykke og den absolutte selvbestemmelsesrett. I så fall risikerer vi å undergrave befolkningens forventninger til helsetjenesten.

\section{LITTERATUR}

1. Lov 2008-o6-20 nr 44: Lov om medisinsk og helsefaglig forskning (helseforskningsloven) www.lovdata.no/all/hl-2008o620-044.html (2.3.2011).

2. Helsinkideklarasjonen www.wma.net/en/3opublications/1opolicies/b3/index.html (2.3. 2011).

3. HUNT Helseundersøkelsen i Nord-Trønderlag. HUNT og NTNU mot 2020. Status og muligheter. www.ntnu.no/c/document_library/get_file?uuid=c3db159c-dafc-4d16-b626e7bc3a65586e\&groupId=10304 (3.3.2011).

4. Nürnbergprosessen. http://nuremberg.law.harvard.edu/php/docs_swi.php?DI=1\&text=overview (3.3.2011).

5. Simonsen S. Acceptable risk and the requirement of proportionality in european biomedical law. Doktoravhandling. Trondheim: Norges teknisk-naturvitenskapelige universitet, 2010:16.

6. Berger O. Fra informert til fordekt samtykke? Tidsskr Nor Legeforen 2010; 130: 2212.

7. Lov-20oo-04-14 $\mathrm{nr}$ 31: Lov om behandling av personopplysninger (personopplysningsloven). www.lovdata.no/all/nl-20000414-031.html (7.12.2010).

8. Ruyter KW, Lõuk K, Jorqui M, et al. From research exemption to research norm: recognising an alternative to consent for large scalebiobank Research Medical Law International 2010;10: 287-00-o.

9. The Data Protection Directive (95/46/EC) www.dataprotection.ie/viewdoc.asp?DocID=89 (3.3.2011).

10. Lov 2006-o6-30 nr 56: Lov om behandling av etikk og redelighet i forskning. www.lovdata.no/all/nl-2006o630-056.html (7.12.2010).

Publisert: 20. mai 2011. Tidsskr Nor Legeforen. DOI: 10.4045/tidsskr.11.0210

Mottatt 10.2. 2011, første revisjon innsendt 9.3. 2011, godkjent 17.3. 2011. Medisinsk redaktør Are Brean. (C) Tidsskrift for Den norske legeforening 2023. Lastet ned fra tidsskriftet.no 26. april 2023. 